\section{Indremedisinsk bredde i lommeformat}

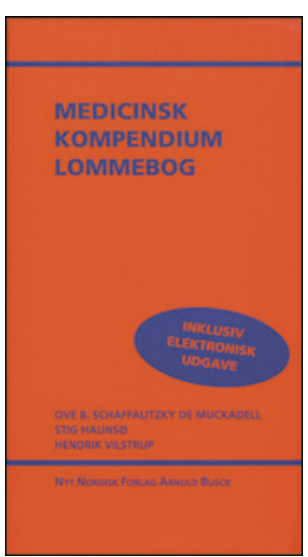

Ove Schaffalitzky de Muckadell, Stig Hauns $\varnothing$, Hendrik Vilstrup Medicinsk kompendium lommebog

5. utg. 664 s, tab, ill. København: Nyt Nordisk Forlag Arnold Busck, 2015. Pris DKK 700 ISBN 978-87-17-04535-4

Med Medicinsk kompendium lommebog forsøker de danske forfatterne av tobindsmastodonten Medicinsk kompendium - som ikke er spesielt hendig - å sammenfatte hele indremedisinen i en bok liten nok for frakkelommen. Den lille størrelsen og det avlange formatet innbyr til hyppig og raskt å finne frem detaljer om sykdomstilstander og annen medisinsk informasjon i klinisk praksis.

Boken har en typisk seksjons- og kapittelinndeling i organsystemer og sykdomsgrupper. Den har også en egen seksjon for kliniske kardinalmanifestasjoner, og et kapittel med alle tenkelige medisinske forkortelser skrevet helt ut. Sistnevnte er svært nyttig i mottakstjenester som legevakt og akuttmottak, hvor man ofte møter et vidt spekter av lidelser og tidligere spesialistbehandlinger med særegne forkortelser og akronymer. Kapitlet om rettsmedisin blir mindre relevant i Norge, ettersom boken er dansk, men generelt er det lite overflødig innhold. Detaljnivået er godt balansert til å være en sammenfatning av et stort fagfelt.

Til forskjell fra andre bøker med samme formål og format, slik som Oxford handbook of clinical medicine, er Medicinsk kompendium lommebog nærmest blottet for figurer og illustrasjoner. Unntakene, som EKG-utskrifter og illustrasjoner av affiserte ledd ved revmatiske sykdommer, er dessuten uten farger. Generelt fremstår boken som ganske grå og kjedelig.

Boken har en særegen sidenummerering som jeg etter lang tids bruk fremdeles er usikker på om tilfører noe mer enn konvensjonelle sidetall. For eksempel er side fire i kapittel 41 om sykdommer i kalsiummetabolismen merket 41-4. En medfølgende kode til elektronisk utgave av boken mener jeg er unødvendig: Ønsker man innholdet elektronisk, finnes boken $i$ en egen app-versjon til omtrent halve prisen av den fysiske utgaven.

Alt $i$ alt er Medicinsk kompendium lommebog en svært anvendelig oppsummering av det mest sentrale på det indremedisinske feltet, og den egner seg særlig til bruk i legevakt og akuttmottak.

Frederik Emil Juul

Turnuslege, Sykehuset Innlandet

Hamar

\section{Kvalitetssikring i psykiatrien}

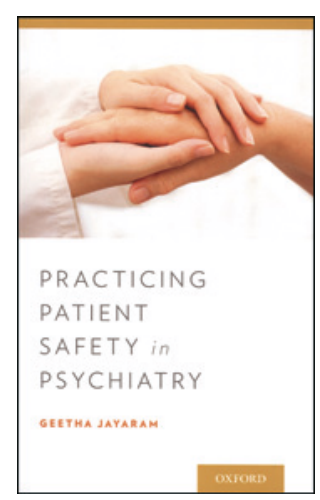

Geetha Jayaram

Practicing patient safety in psychiatry

175 s, tab, ill. Oxford: Oxford University Press, 2015. Pris GBP 23

ISBN 978-0-19-997176-3

Målet med denne utgivelsen om pasientsikkerhet i psykiatrien er å gi en oversikt over hvilke faktorer som påvirker god behandling, behandlings- og pasientsikkerhet og å angi hvorledes disse faktorene kan ivaretas. Forfatteren har en i årrekke ledet et utvalg om pasientsikkerhet nedsatt av den amerikanske psykiatriforeningen. Målgruppen er psykiatere og leger i spesialisering i psykiatri.

Boken omhandler blant annet organisering av løpende kvalitetssikringsarbeid og hvordan man skal analysere årsakskjedene til feil. Den gir en oversikt over risikofaktorer for selvmord under psykiatrisk behandling og forebyggende tiltak. Videre gir den oversikt over tilsvarende risikofaktorer og forebyggende tiltak både ved elektrokonvulsiv terapi (ECT), ved rømming fra en innleggelsessituasjon og ved overlevering av pasient fra en behandlingssammenheng til den neste. Forfatteren tar også for seg psykiatriske pasienter i somatiske sykehus.

Hvert kapittel innledes med kasuistikker og avsluttes med konklusjon og «ta med hjem-poenger». Kapitlene har litteraturreferanser frem til ca. 2010, og det er også et stikkordregister. Formatet passer i frakkelommen, papir og trykk er godt, skriften er stor, og kapitlene er oversiktlig organisert med underoverskrifter og kulepunkter.

Boken bør leses minst to ganger. Ved første øyekast kan man bli oppgitt over alle selvfølgelighetene som presenteres. Ved neste gangs gjennomlesning kommer erkjennelsen av at dette er en liten perle, med en stikkordsmessig oversikt over alle forhold som bør vurderes og håndteres for å forebygge, unngå og lære av feil på flere nivåer.

Kapitlet Physician Advisor om en psykiatrisk storavdeling/klinikk, er tankevekkende. Jeg kjenner ikke til noe tilsvarende i Norge. Vedkommende - en «physician advisor» - er en slags klinisk arbeidende avdelingsoverlege/spesiallege uten administrativt, økonomisk eller arbeidsgiveransvar og uten medisinskfaglig systemansvar. Til gjengjeld har denne legen myndighet til å gå inn i alle feil, ulykker og nestenulykker, til å analysere dem med hensyn til årsaksforhold og håndtering og til å avdekke muligheter for feil og ulykker. Denne spesiallegens vurderinger går på alle nivåer, fra institusjonens løpende vurdering av den enkelte ansattes helse og kompetanse, via hvordan videreutdanning av leger er lagt opp, til organisatoriske og bygningsmessige forhold. Det er nettopp det gjennomgående ansvaret for rådgivning og tiltak både for enkelthendelser og løpende kvalitetssikringsarbeid i institusjonen som gjør denne stillingen unik. Om ledelsen fraviker spesiallegens vurderinger og anbefalinger, sitter ledelsen igjen med ansvaret.

Jeg tror ikke det finnes en tilsvarende bok på norsk. Den vil nok allikevel - dessverre - neppe bli lest av andre enn kolleger med særlig interesse og ansvar for kvalitetssikringsarbeid. Den burde bli lest av alle, ikke minst av tillitsvalgte, som ønsker å styrke faglighet og pasientsikkerhet i en New Public Management-preget helseforetaksverden.

Asbjørn Restan

Avdelingsoverlege, Psykiatrisk avdeling - Blakstad Vestre Viken 